UDC 811.111'22:801.73

\title{
FROM TEXT TO POLYCODE TEXT: SEMIOTIC CHANGES IN TEXT PRODUCTION
}

\author{
Tetiana Semeniuk, Yulia Gordienko, \\ $\mathrm{PhD}$ in Philology, \\ Assistant Lecturer of the Department of Foreign Languages for the Humanities, \\ Lesya Ukrainka Eastern European National University, \\ Lutsk, Ukraine \\ faltan@ukr.net, yulia.gord.8@gmail.com \\ Received May, 7, 2018; Accepted May, 31, 2018
}

\begin{abstract}
The article is devoted to the investigation of the linguistic notions of "text" and "polycode text". The notion of a text has recently undergone a lot of changes in its interpretation. Nowadays, while defining of texts it has been offered to take into account different approaches to their study including not only grammatical, cognitive-semantic, communicative-pragmatic, but also semiotic and semioticcultural. The development of IT, the globalization, and changes in the ways of coding of information have increased the role of the semiotic approach in the interpretation of texts. Within the semiotic approach, today's text is regarded as a set of monocode or polycode communicative resources which correlate with each other, form a complex integrative meaning and are addressed to recipients with a certain pragmatic purpose. It has been proposed to distinguish between monocode and polycode texts and to use the term "polycode" to accentuate the coexistence of two or more codes in one text space. A polycode text is regarded in the article as a coherent unit consisting of several semiotic codes: verbal, non-verbal (photographs, pictures, pictograms, ideograms, smiles, cartoons, tables), paraverbal (color, font, punctuation, layout, diacritical marks). Changes in the encoding of the information in texts and the emergence of new communicative resources have led to the necessity of the reviewing of text's textuality. Polycoding and multimodality have been regarded in the research as standarts of textuality as well as cohesion, coherence, intentionality, acceptability, informativity, situationality and intertextuality.
\end{abstract}

Key words: text, polycode text, verbal, non-verbal, paraverbal resources, semiotic approach.

\section{Introduction}

Such changes in the globalized society as the emergence of new multimedia technologies, the computerization, and the tendency towards visualization have changed the ways of human communication and modified conventional ways of coding of information. The new semiotic dominants such as images, photographs, sounds, colors, design, layout are becoming significant in communicating and meaning-making of contemporary texts. It has been stated that "the meaning is realized not only through language but also through the integrated use of a wide range of semiotic resources including static and dynamic ones" (Jing Liu, 2013: 1259). It is worth mentioning that today's texts are rarely only verbal structures, they often consist of different semiotic codes with predominance either of verbal or non-verbal 
resources, sometimes texts include only non-verbal and paraverbal signs (e.g. advertising text without verbal components).

It must be pointed out that the meaning of the texts in written discourse is made with far more than verbal signs because other semiotic codes become integral parts of the text structure and its meaning. It should be stressed that all semiotic resources and their correlations must be considered while studying the meaning-making resources which form the texts.

Changing in the semiotic status of a text became the subject of scientific research in the last decades of the 19 century. In 1990 German linguist H. Schröder noted that "new communication technologies would play an increasingly important role in the future and would change our perceptions of what the text is" (Schröder, 1993: 191). Nowadays the scientists point out that the notion of "text" cannot be used in the future only to refer to a verbal communicative structure (Hoffmann, 2004: 357). It has also been said that written text is only one part of the message and no longer the dominant one (Heath, 2000; Bearne, 2003).

The level of the integration of all visual aids as well as other iconic signs into a single textual space of printed and electronic publications is very high. There may be several codes included in the semiotic space of written texts. According to the criterion "the number of semiotic codes", all texts can be classified into monocode and polycode ones. Monocode texts as a semantic set of symbols of one semiotic system (mainly verbal) occur today more rarely than the polycode ones. Polycode texts in which the message is coded by semiotic heterogeneous means (verbal, non-verbal and paraverbal) are developing new ways of communication.

The integration of non-verbal and paraverbal semiotic resources in the semantic space of traditional verbal texts apparently contributed to the change of their semiotic status, having led to the necessity of the revision of the definition of a text and its textual criteria.

\section{Different approaches to the definition of a text in the modern linguistic paradigm}

In the modern scientific paradigm, a text is regarded as one of the key notions of linguistics, a means of expressing and storing of human knowledge, and the basis of culture and civilization. Despite the fact that there are many definitions of the notion of a text in the linguistic scientific literature, they do not always correspond to the modern scientific tendencies and sometimes even contradict the latest trends and visions. Therefore, the primary task of this issue is to review approaches to defining of the notion "text" and outline its characteristics within the modern linguistic paradigm.

Numerous definitions of the concept "text" in the modern linguistics may be explained by a) the formal-structural variability of texts; b) their functional and stylistic diversity; c) the difference in the approaches to the study of the text; d) the absoluteness of its formal-structural aspects, the orientation of the definition of the text into one or several categories (Selivanova, 2011: 26-29). 
In linguistics the most widespread definition of a text was made by I. Galperin who considers it as:

"Completeness objectified in the form of a written document; formation in accordance with the type of the document; structure represented by a title/ heading and a number of supra-phrasal unities which are brought together by different types of lexical, grammatical, logical, and stylistic links and serve for certain pragmatic purpose" (Galperin, 1981: 18).

Despite the carefulness of this definition of the text, scholars criticize such aspect as "objectified only in a written form", noting that the proposed definition covers only texts in written form (Jeshchenko, 2009: 129). According to the semiotic approach, other forms such as music, dance as they are performed as well as static manifestations (e.g. portrait, still-life) are also texts. To avoid the discussions concerning the statements that texts are written massages, it has been suggested to understand the studied phenomenon as a structurally and conceptually organized oral, written or printed verbal unit which is the result of communication.

Obviously, the narrowing of the concept of the text to the written speech form can be explained by the existence of such linguistic concept as "discourse", which is interpreted as:

"The type of communicative activity, the interactive phenomenon; the speech which has different forms of expression (oral, written, paralingual), occurs within the concrete channel of communication, is regulated by the strategies and tactics of the participants of communication; synthesis of cognitive, lingual and extra-lingual (social, psychological) factors" (Batsevych, 2004: 138).

Some linguists make a distinction between the notion "text" viewed as a physical product, a result of communicational events and "discourse" viewed as a dynamic process of expression and interpretation of information. As stated by F. Batsevych,

"a text is the result of communication, its structural and linguistic component, and, at the same time, its final realization; the structure in which the "living" discourse is embodied after its completion (Batsevych, 2004: 147).

In the above-mentioned interpretation, the text appears as a "stopped" discourse without its participants, place, time and communication circumstances. Consequently, discourse is a broader concept than a text it is the process of speech activity while the text is regarded as its result.

In addition to the problem of the interpretation of a text within a discourse, linguists more often tend to deal with the problem of defining it by means of different approaches to the study of this phenomenon. The analysis of scientific research of the outlined problem has shown that the main parameters of the text, that were used as the basis for its definition, were grammatical (predominately, the syntactic ones) and categorical features.

In the modern linguistic paradigm, there are different approaches to the text studying. The conventional one is the grammatical or syntactic approach. Representatives of the grammatical approach define a text as the highest grammatical unit which represents the coherent sequence of sentences (Brinker, 2010: 14); a coherent sequence of sentences combined in one context within the general intention of the author (Nikolajeva, 1978: 6); a communicative occurrence which meets seven 
standards of textuality (if any of these standards is not considered to have been satisfied, the text will be treated as non-text) (Beaugrande, Dressler, 1981: 3). Consequently, within the grammatical approach, the text can be considered as a coherent sequence of sentences.

According to the cognitive-semantic approach to the linguistic description of a text, the main emphasis in text analysis is laid not only on the surface structure of a text but on the semantic relationships between parts of a text. A text is defined as a semantic wholeness which is organized by the unity of its constituent elements (Galperin, 1981: 87). Within this approach, a text is regarded as a meaningful integrity or a complex of mental resources and concepts which form the integral semantic and conceptual field of the author and recipients.

Many approaches to the text description may be used within one definition in order to accentuate the main features of this phenomenon. Thus, A. Zagnitko (Zagnitko, 2010: 169) emphasizes the structural and semantic integrity of a text and defines it as a written or oral coherent unit, a linear sequence of statements, connected by thematic, logical, semantic, and formal-grammatical relations.

In the last decades of the last century, the communicative-pragmatic approach to the understanding of text became of particular relevance. The main idea of this approach is to emphasize the communicative function and intention of the text content, as well as to stress that "a text is to serve as a vehicle for a transmission of the author's intended meaning to the reader" (Leewen, 1981: 10). Thus, a text without communicative function is not a text. O. Selivanova qualifies the investigated linguistic phenomenon as:

"The holistic semiotic form of mental and speech human activity, conceptually and structurally organized, dialogically included in the interior existence; the semiotic universe of the ethnic group or civilization which is a pragmatically directed mediator of communication" (Selivanova, 2008: 495).

Within communicative-pragmatic approach, a text may be defined as a means of verbal communication and conveying information; a pragmatic element or a middle component of a communicative act between the addresser and the addressee.

At the present stage of the development of linguistics, the semiotic approach to the understanding of a text is of considerable interest of many scholars. Changes occurring in the methods of coding information have contributed to the modification of the semiotic structure of the text. So, the definition of the text as the one made by V. Bogdanov (Bogdanov, 1993: 5) who defines this phenomenon as linguistic material, fixed on one or another medium by means of a written essay (usually phonographic or ideographic), is not actual nowadays. Firstly, this definition indicates that the text has a productive, static nature; it is fixed in space and time by a sign product. Secondly, the text has a linguistic nature, that is, it consists precisely of verbal signs and is a verbal sign itself. The last statement is controversial because modern texts are not seen today as only language units.

Text as a verbal, "classical" form of information is less popular as semiotic heterogeneous complex. In semiotics, the text is understood as any sign, any form of communication, including picture, dance, and road signs. According to the semiotic approach, today's texts are mainly heterogeneous phenomena, the sets of semiotic elements, which have a formal connectivity and meaningful integrity. 
Taking into account semiotic features K. Guazenblas (Gausenblas, 1978) distinguishes between three types of texts: a) linguistic (verbal) texts (e.g. business, scientific), b) extralinguistic (non-verbal) (e.g. music work, dance) and c) mixed texts with dominance of either verbal or nonverbal components (e.g., comics, advertising messages, advertising posters, television advertising, radio advertising).

The semiotic approach to the text studying is closely connected with the semiotic-cultural one. The main idea of the modern semiotic theory of culture is that each culture is the system of signs. According to R. Posner (Posner, 2004: 71), it is advisable not only to understand a civilization as a set of artifacts but also to regard it as a set of texts in the broad sense of cultural semiotics. Thus, it must be said that texts are important parts of cultural and spiritual life. From the semiotic-cultural point of view, text is defined as any fact of a human sign activity that has cultural significance; it's a phenomenon of culture (Khalizev, 2002: 276). So, the creation of any text, as well as any other object of culture, is oriented to extralinguistic reality, it is preceded by the spiritual sign activity of people, because the author (i.e., writer, artist, sculptor, architect, folk master) first of all comprehends the idea of the work and then embodies it with the help of a certain sign system. According to the semiotic-cultural approach, the text is a cultural complex which embodies cultural realities with extremely powerful meanings.

In particular, Yu. Datchenko explores pysankas which are treated as visual and cultural complexes with a peculiar encoded text performed by non-verbal means (lines, colors) (Datchenko, 2015: 6). Pysankas, artistic fine artworks (paintings) and works of folk artists (embroidery, woven products) are texts because they incorporate and represent a certain meaning through the system of conventional codes.

In our study, we would like to emphasize the importance of the interdisciplinary approach to the understanding of a text which could be described as a linguistic, cultural, cognitive, communicative, and semiotic event (Semeniuk, 2017). Taking into account the heterogeneous character of today's communication, we believe that the semiotic approach of the text understanding is especially important at the present stage of communication development. J. Bateman and K. Schmidt say that nowadays text is just one strand in a complex presentational form that seamlessly incorporates visual aspect 'around,' and sometimes even instead of, the text itself (Bateman \& Schmidt, 2011).

Summing up the above-mentioned facts and thoughts, we assume that the intersemiotic nature of modern communication (both oral and written) should be reflected in the definition of the investigated communicative phenomenon. We agree with the definition of the text offered by E. Anisimova:

"The text is a unit of speech communication aimed at a certain pragmatic influence; its elements (verbal and non-verbal) form a structurally, semantically and functionally completed wholeness" (Anisimova, 2003: 36).

We are also impressed by the interpretation of a text offered by O. Selivanova who defines it as a holistic semiotic form of the linguistic and psychological activity of the speaker, conceptually and structurally integrated, serving as a pragmatic mediator of communication and dialogically embedded in the semiotic space of culture (Selivanova, 2015: 112). 
Consequently, having considered a number of definitions of the text, within our scientific research we want to emphasize the multidimensionality of this linguistic phenomenon, in determining which one must take into account not only its grammatical, semantic, pragmatic, but also semiotic parameters which indicate the nature of the text as a sign complex.

At the present stage of the development of linguistics, we propose to define a text as a complex of monocode or polycode communicative elements which correlate with each other, form a complex integrative meaning, and are addressed to a certain circle of recipients in order to achieve a perlocutive effect.

Changes in the semiotic structure of texts have modified their textuality or texture. So, the seven principles of textuality offered by R. de Beaugrande and W. Dressler: intentionality (having a plan or purpose); acceptability (having some use for the receiver); situationality (relevance to the context); informativity (degree of new information); and intertextuality (relations with other texts) have to be supplemented with polycoding (the availability of codes of different semiotic systems in one text) and multimodality (the ability to decode information simultaneously through different sensor channels).

\section{Polycode text and the problem of its nomination}

It is hardly possible to view today's texts as merely verbal phenomena. It has been stated that "texts never exist only verbally because signs of other semiotic systems coexist with them"(Fix, 2008: 31). Linguists say that "to focus only on the language and to ignore the other modes means to miss a lot of the potential meanings of modern texts" (Kibrik, 2010: 147). As far as semiotic resources form a single meaning of the heterogeneous text they shouldn't be disregarded because it is impossible to understand the meaning of the whole text only by one verbal code.

When dealing with semiotically heterogeneous texts it should be clarified which semiotic resources are used for their meaning-making. According to E. Anisimova, non-verbal and paraverbal elements of written communication include:

"the graphic segmentation of the text and its location on the paper; the line spacing, font, color, and italicization of textual material; the inclusion of typographic signs, graphic symbols, numbers, and some subsidiary signs (e. g: №, \%, +); icons (pictures, photos, cartoons, drawings, tables, diagrams), unusual spelling of words or punctuation marks; and other characteristics such as paper format, margins, text width" (Anisimova, 2003: 7).

We suggest distinguishing three groups of semiotic codes in written communication: "linguistic -- paralinguistic - non-linguistic" or "verbal paraverbal - non-verbal". The verbal code is represented by linguistic means of various levels (e.g. words, phrases, sentences). The non-verbal code of written communication includes iconic elements which "form the dominant field of paralinguistic devices of the text" (Anisimova, 2003: 8). Iconicity has been understood as a relationship of resemblance or similarity between two domains: form (phonology) and meaning (semantics). "Form" can refer to phonological segments that comprise the sign (imagic iconicity), but also to the way linguistic elements are 
organized with respect to each other (diagrammatic iconicity). "Meaning" refers to lexical meaning as well as to more abstract and grammatical functions, such as plurality, anteriority and others (Meir, 2013).It has been offered to classify iconic elements in 1) realistic icons (photos, portraits, landscapes); 2) logical-schematic icons (geographical maps, plans of the areas); 3) symbolic icons (pictograms, metaphorical images) and 4) conventionally-schematic icons (cartoons, comics) (Semeniuk, 2017: 59).

Sometimes non-verbal and paraverbal devices of written communication are viewed by scientists only as illustrations or aesthetic additions to the text. German linguists were among the first ones who began to emphasize the importance of images in constructing of the meaning-making. Thus, G. Stöckl criticized the opinion of the scholars who recognized the priority of verbal means of coding of information, emphasizing that "unfortunately, the material image is considered most likely as a secondary sign resource which is characterized by the less intellectual attractiveness" (Stöckl, 2004: 102). In later works, the linguist emphasized the role of images which are considered by him to be the most important sign resources of presentation, interpretation and perception of the information. Nowadays it is impossible to imagine modern texts without non-verbal, and paraverbal devices.

The semiotic approach allows classifying of all texts into monocode (homogeneous) and polycode (heterogeneous). It should be mentioned that the opposition of mono- and polycode texts was first used by H. Eiger and V. Yuht in 1974. Polycode texts are defined as a combination of the verbal code with the codes of some other semiotic systems (images, music) (Eiger \& Yuht, 1974:107). All nonverbal and paraverbal means play a significant role in the semantic organization of the text and its communicative pragmatic aspect.

The keen interest of scientists in the study of polycode or semiotically heterogeneous text led to the emergence of various nominations for the studied phenomenon. The first attempts to investigate texts with semiotically heterogeneous components were made in psycholinguistics. Today linguists use numerous terms for the nomination of semiotically heterogeneous texts. Among the most widespread ones are creolized text, semiotically complicated text, heterogeneous text, polycode text, polymodal, multimodal text, multicommunicative text, contaminated text, hybrid text, picture-verbal, video-verbal, intersemiotic text, verbal-iconic text, visual text, visually dependent text. In order to understand the meaning of the above-mentioned terms, we will try to consider the nominations and definitions of the most used ones and determine their use.

In 1990 the term "creolized text" was proposed by Yu. Sorokin and E. Tarasov (Sorokin \& Tarasov, 1990: 187). In linguistics, the metaphorical term "creolized text" is used by such researchers as A. Adzinova, E. Anisimova, A. Bernatskaya. The word "creolization" means the combination of means of various semiotic systems in a complex that should conform to the criterions of textuality (Bernatskaya, $2000: 109$ ). The creolized text is a special kind of texts, the texture of which consists of two nonhomogeneous parts: verbal and nonverbal, which belongs to other sign systems (Sorokin \& Tarasov, 1990: 180-181). E. Anisimova clarifies the concept of creolized text as such, "in which verbal and nonverbal components form one visual, structural, semantic and functional wholeness, aimed at the complex pragmatic influence on the 
addressee" (Anisimova, 2003: 73). The creolized texts include cinema texts, radio texts and television texts, means of visual agitation and propaganda, posters, advertising texts, books with illustrations.

However, the term "creolized text" causes a number of contradictions and ambiguous thoughts among other linguists. Furthermore, it is associated with creolization which was first understood as the process of formation of new ethnic groups by mixing the blood of several contacting ethnic groups. In our opinion, modern linguistic understanding of the process of "creolization" has nothing to do with its initial values, and sometimes leads to confusion due to the existence of various processes which are designated by the same term.

Today linguists actively use the term "multimodal" to denote semiotically complicated texts. They say the term "multimodal" is derived from the word "mode" or "modality." So, to define multimodal texts it should first be clarified what is meant by "mode" vs. "modality." G. Kress states that a mode "is a socially and culturally conditioned semiotic resource for making meaning (Kress, 2010). A mode is a complex of various factors. It is a sign system including 1) pictorial signs; 2) written signs; 3) spoken signs; 4) gestures; 5) sounds; 6) music; 7) smells; 8) tastes; 9) touch interpretable because of a specific perception process. Ch. Forceville emphasizes that:

"The modes are linked one-on-one to the five senses, so that we would arrive at the following list: 1) the pictorial or visual mode; 2) the aural or sonic mode; 3) the olfactory mode; 4) the gustatory mode; and 5) the tactile mode" (Forceville, 2006).

English scholars define multimodality as a combination of different semiotic modes - for example, language and music - in a communicative artifact or event (van Leeuwen, 2005: 28).

German and Russian scholars believe the term "multimodal" is derived from the term "modality". It is pointed out that modality includes semiotic resources related to a certain sensory aspect (auditory, visual). A. Kibrik emphasizes, that modality is a type of external stimulus, perceived by one of the human senses, primarily by sight and hearing (Kibrik, 2010: 135). Moreover, the term "multimodal text", which is popular among English scholars to denote the combination of two or more of modes to create meaning, is rarely used in German linguistic studies. W. Schnotz and H. Horz consider that multimedia information resources contain information, which has different forms of coding (text, images) (multicode, Multikodalität) and is perceived mainly in different modalities (printed text through the visual channel and oral through audio channel) (multimodal, Multimodalität) (Schnotz \& Horz, 2009: 88).

W. Holly distinguishes between codes and modes. Codes are material qualities in sign making, while modes embody the qualities of perception as processing modes in the character reception (auditory, visual, etc.) (Holly, 2009: 392). In this case, it has been offered to differentiate between the notions of "polycode text", "multicode text" or "multicodal text" and "multimodal text." It has been proposed to use the term "polycode text" for denoting texts which consist of two or more codes that are perceived through one or more sensory channel. The term "multimodal text" should be used if the recipient uses different sensory modalities while decoding the information.

There are different sensory modalities that can be used to perceive the information in the communicative process. The main sensory channels are visual, 
auditory (sonic) and haptic (tactile-kinesthetic). So, the meaning of the texts can be decoded through visual, auditory and even through tactile-kinesthetic modalities. For example, a book with text and pictures, a printed advertisement are perceived only visually. The content of an audio-book without accompanying images can be decoded through auditory channel. A concert can be both mono- and multimodal: recordings made by a record, tape or CD are purely auditory, but music concerts on TV or live concerts may be perceived with the help of visual, auditory and sometimes even tactile-kinesthetic means (e.g. loud music on a live concert may have contact with our body). Blind people perceive the information either through auditory or tactilekinesthetic modality (they read touching the letters of Braille language). Films on TV are without doubt multimodal texts in which verbal constituents, sounds and images correlate with one another making the coherent meaning of the text.

We believe that multimodality provides the multiplicity of information channels/modalities used in the perceiving of information. For instance, a printed advertising text with verbal and visual parts may be multicodal but monomodal.

To denote the synthesis of verbal and pictorial sign systems linguists use a term "picture-verbal complex" (Bernatskaya, 2000). In our opinion, this term also has some limitations in its application, because such texts may involve only images and verbal components. So, the use of the term "picture-verbal complex" will not be correct in relation to texts with other non-verbal resources such as color, graphic segmentation of text, font, graphic symbols, audio elements.

O. Poimanova proposes to denote semiotically heterogeneous texts "videoverbal." The scholar points out, that such texts consist of a sequence of signs which are in semantic correlations and belong to different sign systems: the natural language and the iconic one (Poimanova, 1997: 21). We consider the use of this term as well as the term "picture-verbal complex" to be limited to texts, in which the constituent parts are only images or other iconic signs. It cannot be used to denote other semiotically complicated texts, which include, for example, audio parts (i.e., sounds, music) as well as music clips or videos.

Sometimes semiotically complicated texts are called "visual texts" which are defined as texts formed by a combination of visual resources (camera shots, still pictures and graphics) and verbal resources (words, dialogues) to convey a message to the audience. We disagree with the use of this term firstly because it doesn't not mean the audio resources as integral parts of heterogeneous texts, secondly because the term "visual" means "relating to seeing or sight." We insist on the idea that due to the sensory channels of information perception, any written text is visual. According to R. Posner, there are such codes as:

"the auditory (i.e., oral) code of natural language, the non-linguistic auditory code of music, the visual (i.e., written) code of natural language, the non-linguistic visual code of moving pictures (in film, television, video, and computer games), and the plastic code of stone architecture. Thus, both verbal and pictorial codes are perceived visually, so texts with such integral components are certainly visual. Texts with audio resources as well as texts of Braille language cannot be identified as visual texts. It means that the term "visual text" may refer only to semiotically heterogeneous texts perceived through the visual sensory channel" (Posner, 2004: 81). 
Consequently, the use of the terms "picture-verbal text", "video-verbal text", and "visual text" have their own limitations which make it impossible to use the term to refer to audio texts, musicals or films, for which the auditory channel of perception of information should be used to perceive the coded message.

In this research, we are following the views of linguists who use the terms "polycode text" or "polycodal text" in their issues. According to W. Nöth (Nöth, 1990: 206-220), a code consists of a set of signifiers, a set of signifieds, and a set of rules which determine the relation of these to each other. In this issue, a code is understood as a system of symbols and rules of their combination for the transmission, processing, and storage of information.

Thus, a polycode text is a text built of the combination of semiotically heterogeneous components of a verbal text in a single graphic space as well as signs of another semiotic nature (Sonin, 2005: 117). The term "polycode" focuses on the interaction of different codes in one semantic space and draws attention to the textual nature of text, its semantic integrity, and textuality. Therefore, we fully support the opinion of V. Cherniavskaya, who believes that the term "polycode text" is used for denoting a coherent wholeness consisting of several semiotic codes (Cherniavskaya, 2009: 90).

Nowadays the term "polycode text" is actively used by linguists including A.-M. Arias, O. Sonin, V. Chernyavskaya. Taking into account the above mentioned studies we fully agree with the opinion of the scientists who note, that the terms "polycode" and "semiotically complicated" texts are the most effective while denoting the heterogeneous messages (texts) created by various sign systems/codes with the same significance of all semiotic systems involved in the formation of this text.

Changes in the methods of coding information have led to the emergence of new text formats and encouraged scholars not only to review the definition of the text but also its textuality. At the present stage of the development of linguistics, a list of characteristic features of the text such as cohesion, coherence, intentionality, acceptability, informativity, situationality and intertextuality, in our opinion, should be supplemented by such features as polycoding (the availability of codes for different semiotic systems in one text) and multimodality (the ability to decode information simultaneously through different sensor channels).

\section{Conclusions}

With the rapid development of science and technology, the ways of human communication have changed greatly. Today's communication is complex, and the meaning results from the interaction of different semiotic modes, including, e.g., design, layout, images, photographs, film, color and scent. Non-verbal and paraverbal resources are no longer used mainly to entertain and illustrate, today they are becoming significant in communicating and must be taken into consideration while the meaning-making of the semiotically heterogeneous texts.

The variety of semiotic codes which coexist in one communicative space of the texts has caused the necessity of the revision of the notion "text", approaches to its study and its textuality. Among different approaches to the text definition, the 
semiotic approach is very important nowadays. From the semiotic perspective, a text is regarded as a sign system which may be verbal or even non-verbal. A text can be also designed as the variety of codes in which language is only one but not always the essential part.

At the present stage of the development of linguistics, we propose to define a text as a complex of monocode or polycode communicative elements which correlate with each other, form a complex integrative meaning and are addressed to a certain circle of recipients in order to achieve a perlocutive effect.

Modern texts are mainly polycode structures which include the triad of verbal, paraverbal, and non-verbal signs. There are a lot of terms in today's linguistic studies which the scholars use to denote contemporary texts. We believe that the term "polycode text" the most accurately outlines the main features and structure of texts which meaning is formed through the synthesis and interaction of different codes. Taking into account the semiotic character of contemporary texts we offer to review the standards of textuality and to add the polycoding to the principles of textual communication.

\section{References}

Anisimova, Elena. 2003. Lingvistika Teksta i Mezhkulturnaja Kommunikacija (na Materiale Kreoliozovannyh Tekstov). Moscow: Akademija.

—. 1992. "Paralingvistika i Tekst (k Probleme Kreolizovannyh i Gibridnyh Tekstov)". Voprosy Jazykoznanija 1: 71-79.

Arias, Anna-Maria. 2011. "Polikodovyj Tekst kak Semiotiko-Semanticheskoe i Esteticheskoe Znakovoe Edinstvo (na Primere Nemeckoj Karikatury)". Izvestija SanktPeterburgskogo Universiteta Jekonomiki i Finansov 6 (72): 62-65.

Batsevych, Fedir. 2004. Osnovi Komunikativnoji Lingvistiki. Kyiv: Akademija.

Bateman, John, Schmidt, Karl-Heinrich. 2011. Multimodal Film Analysis: How Films Mean. London: Routledge.

Bearne, Eve. 2003. "Rethinking Literacy: Communication, Representation and Text". Reading Literacy and Language 37 (3): 98-103.

Beaugrande, Robert-Allain de, Dressler Wolfgang Ulrich. 1981. Einführung in die Textlinguistik. Tübingen: Niemeyer.

Bernackaja, Ada. 2000. "K Probleme "Kreolizaciji Teksta: Istorija i Sovremennoe Sostojanie”. Rechevoe Obshhenie: Specializirovannyj Vestnik. Krasnojarsk: Krasnojarskij gos. unt. 3 (11): 104-110.

Bogdanov, Valentin. 1993. Tekst i Tekstovoe Obshchenie. Saint Petersburg: Nauka.

Bolshakova, Ljudmila. 2008. "O Soderzhanii Ponjatija "Polikodovyj Tekst". Vestnik SamGU 4 (63): 19-23.

Brinker Klaus, Cölfen, Hermann, Pappert, Steffen. 2010. Linguistische Textanalyse. Eine Einführung in Grundbegriffe und Methoden. Berlin: Erich Schmidt.

Chernjavskaja, Valeria. 2009. Lingvistika Teksta. Polikodovost, Intertekstualnost, Interdiskursivnost. Moscow: URSS.

Datchenko, Julija. 2015. "Interpretacija Pisanki jak Vizuano-Kulturnogo Tekstu". Doslidzhennja z Leksikologiji i Gramatiki Ukrajinskoji Movi. Edit. I. Popova. Dnipropetrovsk: Bila K. O. (16): 3-10.

Eiger, Henrich, Juht, Vladimir. 1974. "K Postroeniju Tipologii Tekstov". Lingvistika teksta: Materialy Nauch. Konerenzii 1: 103-109. 
Fix ,Ulla. 2008. Text und Textlinguistik. Textlinguistik. 15 Einführungen. Hrsg. von Nina Janich. Tübingen: Gunter Narr.

Forceville, Charles. 2006. "Non-verbal and multimodal metaphor in a cognitivist framework: Agendas for research". Gitte Kristiansen, Michel Achard, René Dirven and Francisco Ruiz de Mendoza Ibànez (eds.), Cognitive Linguistics: Current Applications and Future Perspectives: 379-402. Berlin / New York: Mouton de Gruyter.

Galperin, Ilja. 1981. Tekst kak Objekt Lingvisticheskogo Issledovanija. Moscow: Nauka.

Gauzenblaz, Karl. 1978. "O Harakteristike i Klassifikaciji Rechevyh Proizvedenij" Novoe v zarubezhnoj lingvistike 8: 57-78. Moscow

Halizev, Valentin. 2000. Teorija Literatury. Moscow: Vyssh. Shkola.

Heath, S. B. 2000. "Seeing our Way into Learning". Cambridge Journal of Education 30(1): 121-131.

Hoffmann, Michael. 2004. "Zeichenklassen und Zeichenrelationen bei der Verknüpfung von Text und Bild. Ein Beitrag zur semiotischen Semantik". Stabilität und Flexibilität in der Semantik. Strukturelle, kognitive, pragmatische und historische Perspektiven: 357-386 Hrsg. Inge Pohl und Klaus-Peter Konerding. Frankfurt am Main: Peter Lang.

Holly, Werner. 2009. "Der Wort-Bild-Reißverschluss: Über die performative Dynamik audiovisueller Transkriptivität.” Oberfläche und Performanz. Untersuchungen zur Sprache als dynamische Gestalt: 389-406 Hrsg. Angelika Linke, Helmuth Feilke. Tübingen.

Jeshchenko, Tetiana. 2009. Tekst u Lingvistici ta Inshih Filologichnih Naukah. Kyiv: Akademija.

Kibrik, Andrej. 2010. "Multimodalnaja Lingvistika". Kognitivnye Issledovanija 4: 134-152. Moscow: Institut Psihologiji.

Kress, Gunther. (2010). Multimodality: A Social Semiotic Approach to Contemporary Communication. New York: Routledge.

Leewen, Eva. 1981. Sternes "Journal to Eliza": A Semiological and Linguistic Approach to the Text. Tübingen: Narr Verlag.

Liu, Jing. 2016. "Visual Images Interpretive Strategies in Multimodal Texts." Journal of Language Teaching and Researc. 4.6: 1259-263.

Meir, Irit, Padden, Carol, Aronoff, Mark, Sandler, Wendy. 2013. "Competing Iconicities in the Structure of Languages". Cognitive Linguistics. Walter de Gruyter Berlin Boston 24 (2), 309-343. doi: 10.1515/cog-2013-0010.

Nikolaeva, Tatiana. 1978. "Lingvistika teksta: Sovremennoe Sostoianiie i Perspektivy". Novoe v Zarubezhnoj Lingvistike. Moscow: Progress.

Opiłowski, Roman. 2013. "Von der Textlinguistik zur Bildlinguistik. Sprache-BildTexte im neuen Forschungsparadigma". Zeitschrift des Verbandes Polnischer Germanisten 3: 217-225.

Pojmanova, Olga. 1997. Semanticheskoe Prostranstvo Videoverbalnogo Teksta: PhD diss., Moscow State Linguistic University.

Posner, Roland. 2004. "Basic Tasks of Cultural Semiotics". Signs of Power-Power of Signs. Essays in Honor of Jeff Bernard, 56-89Vienna: INST.

Selivanova, Olena. 2015. Osnovyi teorii movnoi komunikatsii. Cherkasy: Vyd-vo Chabanenko Yu. A.

—. 2008. Suchasna lingvistika: naprjamy i problemy. Poltava: Dovkillja.

Semeniuk, Tetiana. 2017. Kognityvno-Semantychni ta Pragmatychni Osoblyvosti Nimeckomovnih Polikodovyh Tekstiv (na Materiali Komertsiinoii Reklamy)". PhD diss., Zaporizhzhya state university. 
Sonin, Alexandr. 2005. Ponimanie Polikodovyh Tekstov: Kognitivnyj Aspekt. Moscow: In-t Jazykoznanija RAN.

Sorokin, Yurii, Tarasov, Evgenii. 1990. "Kreolizovannye Teksty i ih Kommunikativnaja Funktsyia". Optimizacija rechevogo vozdejstvija, 178-187. Edit. by. R. Kotov. Moscow.

Schnotz, Wolfgang, Horz, Holger. 2009. “Online Lernen mit Texten und Bildern”. Online - Lernen. Handbuch für Wissenschaft und Praxis, 87-105. Hrsg. Paul Klimsa, Ludwig J. Issing. München: Oldenbourg.

Schröder, Hartmut. 1993. "Semiotische Aspekte multimodaler Texte". Fachtextpragmatik, 189-21. Hrsg. Hartmut Stöck1. Tübingen: Narr.

Stöckl, Hartmut. 2004. Die Sprache im Bild-das Bild in der Sprache: zur Verknüpfung von Sprache und Bild im massenmedialen Text. Konzepte, Theorien, Analysemethoden. Berlin; New York: Walter de Gruyter.

Van Leeuwen, Theo. 2005. Introducing Social Semiotics. London: Routledge.

Weidenmann, Bernd. 1995. "Multicodierung und Multimodalität im Lernprozess". Information und Lernen mit Multimedia, 65-84. Hrsg. L.J. Issing, P. Klimsa. Weinheim: Psychologie-Verlagsunion.

Zahnitko, Anatolii. 2010. “Tekst: Rivni, Odynytsi, Katehorii, Funktsii, Osoblyvosti Zviazku”, 165-169. Accessed January 2017. https://digilib.phil.muni.cz/bitstream/handle/11222.digilib/128814/Books_2010_2019_0182013-1_24.pdf 